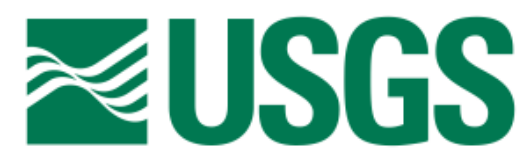

science for a changing world

\title{
Geologic Map of the Lead Mountain 15' Quadrangle, San Bernardino County, California
}

Pamphlet to accompany

Geologic Quadrangle Map GQ-1766

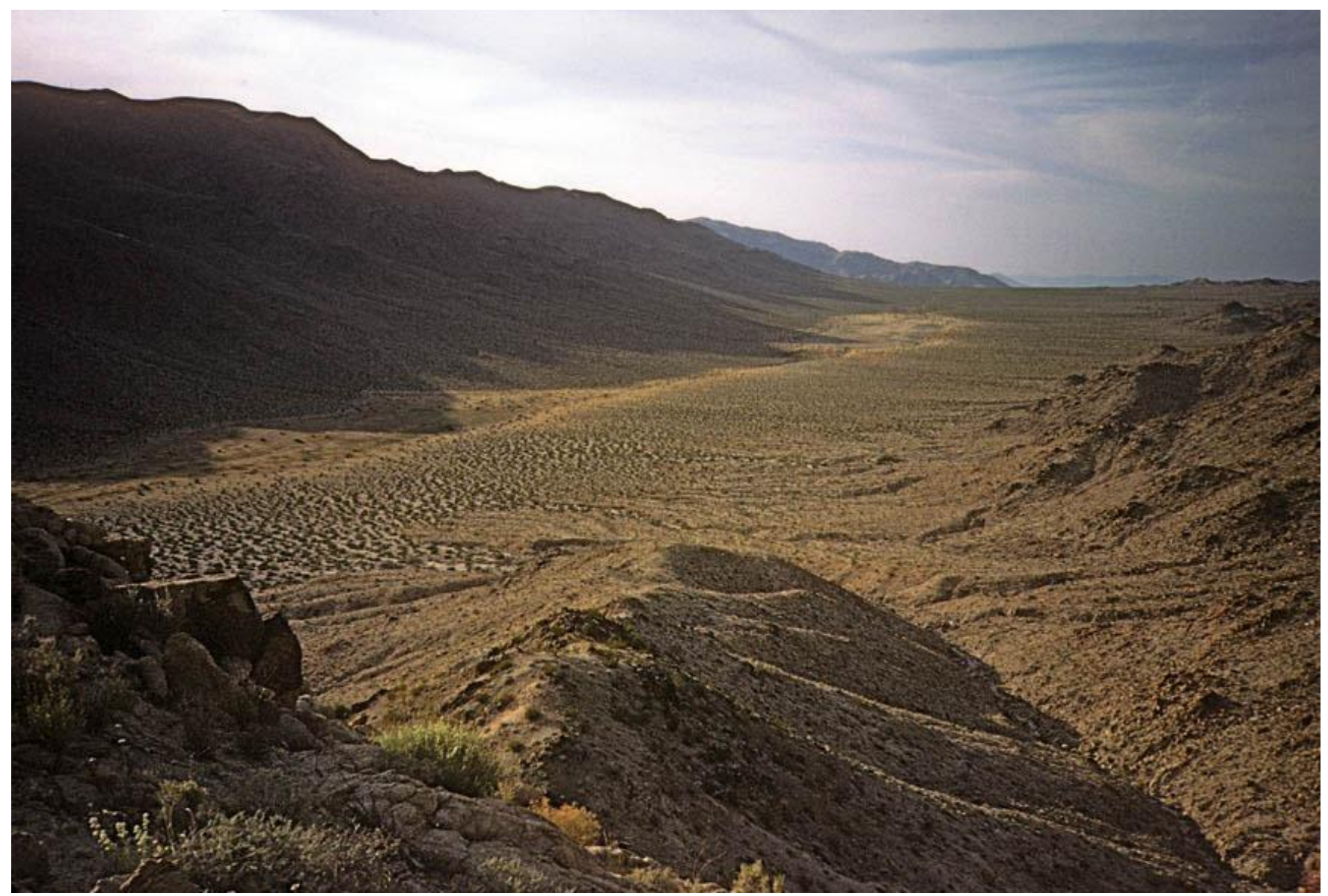

Linear valley along the Cleghorn Lakes Fault Zone in the Bullion Mountains largely separates Jurassic quartz monzonite on the left (west) from Cretaceous granite of the Sheep Hole Pass pluton on the right (east). 


\section{Contents}

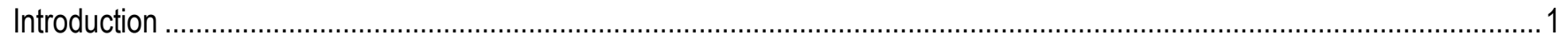

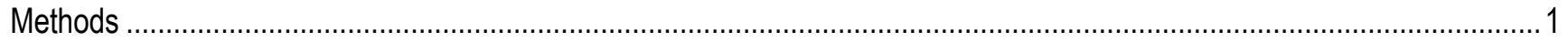

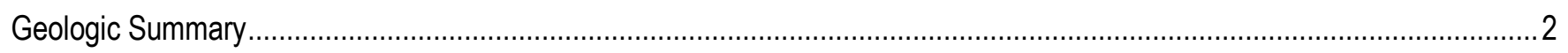

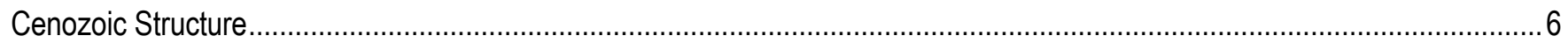

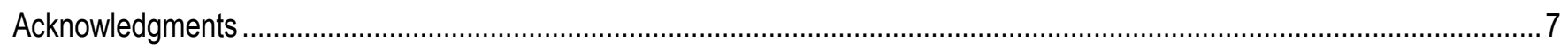

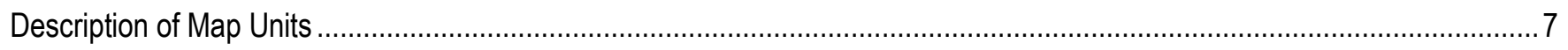

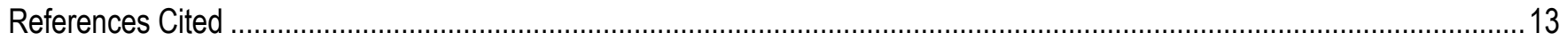

\section{Figures}

1. Map of part of the Mojave Desert showing regional setting of Lead Mountain quadrangle, nearby published generalpurpose geologic maps, and major geographic features. ....................................................................................... 2

2. Map of mountains (shaded) and other geographic features in the Lead Mountain quadrangle........................................ 3

3. Index map of the Lead Mountain quadrangle showing areas of geologic mapping responsibility. ................................... 4

4. Modal mineral proportions in some plutonic rock units. Classification of plutonic rock names is after Streckeisen (1973)....5 


\title{
Geologic Map of the Lead Mountain 15' Quadrangle, San Bernardino County, California
}

\author{
By Keith A. Howard, Keith J. Jagiello1', Todd T. Fitzgibbon, and Barbara E. John
}

\section{Introduction}

The Lead Mountain 15' quadrangle covers the eastern part of the Bullion Mountains and adjacent lowlands in the central Mojave Desert (fig. 1,2). Northwest-trending ranges that form part of the Bullion Mountains are interspersed with broad lowlands in the quadrangle. Rock units within the quadrangle range in age from Proterozoic to Holocene. Arid climate and sparse vegetation result in excellent exposures. Much of the area is within the Marine Corps Air Ground Combat Center (fig. 1), where access must be arranged through the base headquarters.

The geology of the area was previously mapped in reconnaissance (Kupfer and Bassett, 1962; Bishop, 1964). Geologic maps of parts of the area are available in Moyle (1961), in a Ph.D. dissertation (Jagiello, 1991), and in unpublished reports available from Santa Fe Pacific Mining Inc. (Bonham, 1957; Anctil and Schafer, 1958; Cunningham and Bonham, 1958; Cunningham and others, 1958, 1962; Schafer and others, 1959a, b). Geophysical maps of the area include an aeromagnetic map (U.S. Geological Survey, 1981) and gravity maps (Mariano and others, 1986; Jachens and Howard, 1992). Geologic discussions of the area include those by Thompson (1929), Bassett and Kupfer (1964), Parker (1963), Glazner and others (1991), Jagiello and others (1992), Howard and Miller (1992), and Howard (1993, 2002). Mines and mineral deposits in the area have been described in the unpublished reports available from Santa Fe Pacific Mining Inc. listed above, and by Gale (1951), Wright and others (1953), Durrell (1953), Ver Planck (1958), Fife (1985), Gundry (1992), and Neumann and Leszcykowski (1993). Geographic Information System and metadata on most geologic features (except some subunits and small polygons) are available on Geologic map of the Sheep Hole Mountains 30' x 60' quadrangle, San Bernardino and Riverside Counties, California (Howard, 2002) at http://pubs.usgs.gov/mf/2002/2344/.

\section{Methods}

The geologic mapping (fig. 3) was accomplished by field reconnaissance together with the study of geophysical data, photogeology and remote sensing. Approximately 27 person days were spent mapping in the field by U.S. Geological Survey (USGS) crews, and additional field work was performed by Jagiello as part of his Ph.D. dissertation study. Helicopter support for four days provided access to mountains in the eastern third of the quadrangle. Field work concentrated in the area of Cleghorn Pass and to a lesser extent in the areas of Cleghorn Lakes and Lead Mountain. Map compilation locally relied on earlier mapping by Bonham (1957) and Schafer and others (1959b). Contact relations between plutonic units were observed in the field in a few cases as described in the Description of Map Units;

\footnotetext{
${ }^{1}$ Department of Earth and Space Sciences, University of California, Los Angeles
} 
many contacts between units were mapped remotely, using photogeologic study of aerial photographs and remote-sensing images from Landsat Thematic Mapper processed in such a way as to help identify rock units and constituent minerals. An aeromagnetic map (U.S. Geological Survey, 1981) was useful in helping to delineate a contact between the granite east of Cleghorn Pass (Jbe) and adjacent Jurassic units. Mapped concealed faults are partly based on the presence of aeromagnetic gradients.

Mapping was supplemented by study of more than 100 thin sections, by textural study and modal counts of 21 stained plutonic-rock slabs (fig. 4), and by consideration of 17 geochemical analyses (6 done at the University of California at Los Angeles (UCLA) and 11 at the USGS). Spectral properties were determined by spectrophotometer for the 6 samples that were chemically analyzed at UCLA (along with 23 other analyzed samples from adjacent quadrangles) and compared to Landsat-ThematicMapper spectral signatures as part of Jagiello's (1991) remote-sensing study. J.K. Nakata of the USGS dated 6 samples from the quadrangle by the potassium-argon method.

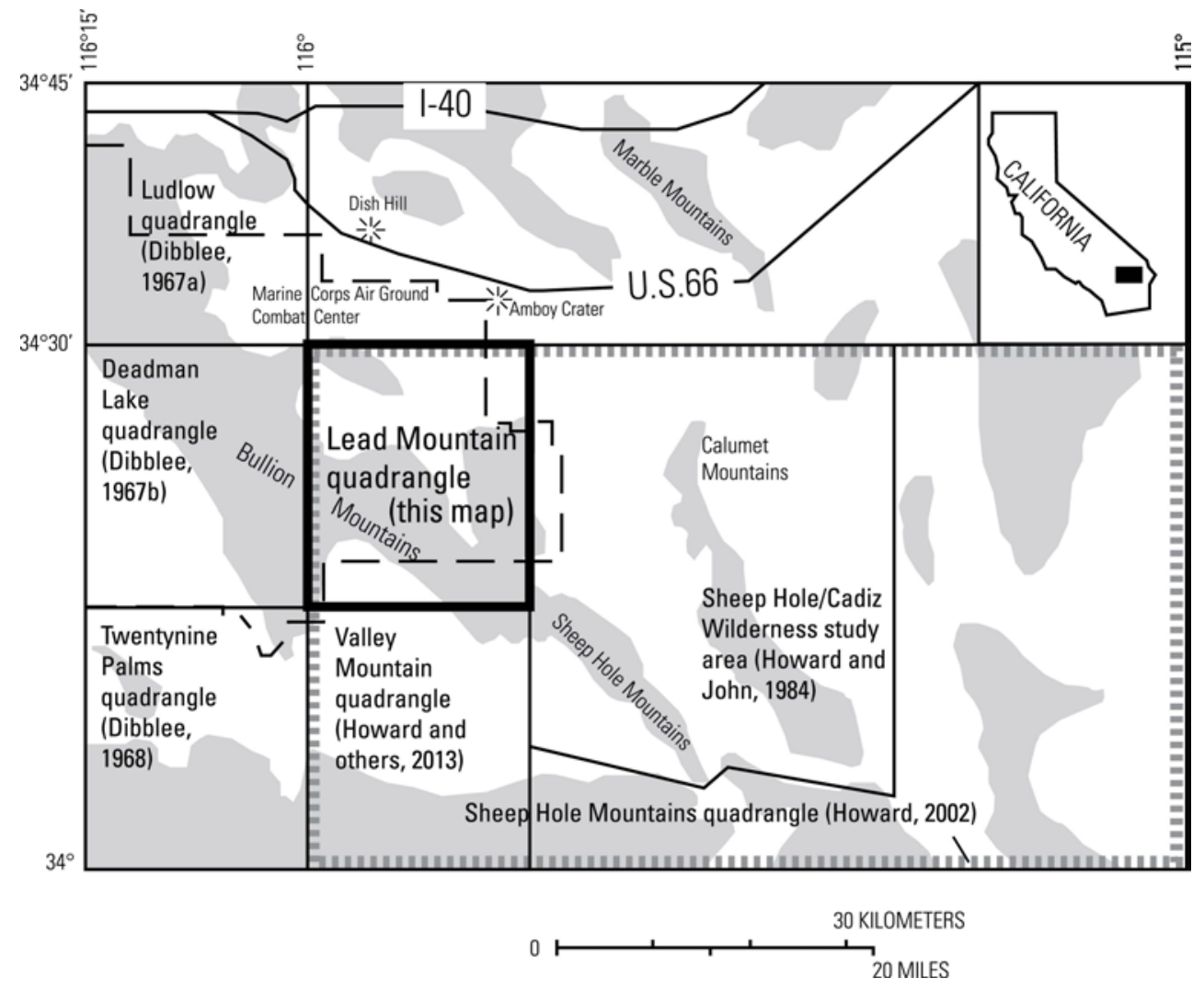

Figure 1. Map of part of the Mojave Desert showing regional setting of Lead Mountain quadrangle, nearby published general-purpose geologic maps, and major geographic features. Mountains are shaded. Surficial geologic maps adjacent to the Lead Mountain quadrangle on the north and northwest were published by Bedford and others (2010) and Phelps and others (2011).

\section{Geologic Summary}

The oldest rocks in the Lead Mountain quadrangle are Proterozoic augen gneiss, metamorphosed plutonic rocks present in the northeastern part of the quadrangle near the America Mine (fig. 2). An assigned age of Mesoproterozoic(?) for these rocks is based on their resemblance to coarse-grained Mesoproterozoic granite (1.4 Ga in age) and augen gneiss recognized to the east in the Marble and northern Calumet Mountains (fig. 1; Silver and McKinney, 1973; Howard, 2002). Proterozoic rocks are 
widespread to the east of the quadrangle but are rare to the west in the central Mojave Desert where Mesozoic batholithic rocks predominate.

The Proterozoic rocks presumably served as a depositional platform for Paleozoic marine rocks that are preserved as pendants enclosed by Mesozoic plutonic rocks. Marble ( $\mathrm{Pzm})$, of probable Paleozoic protolith age, and the metasedimentary gneiss of Sheep Hole Mountains (Mzs), of probable Mesozoic protolith age, form inclusions or pendants surrounded by Cretaceous batholithic rocks in the eastern part of the quadrangle. Rhyolitic rocks assigned to the metavolcanic or hypabyssal rocks unit of Jurassic age are present locally in the south half of the quadrangle.

Mesozoic plutonic rocks in the quadrangle are divided into Jurassic and Cretaceous groups that represent two batholithic events separated in age by dike swarms. Jurassic plutonic rocks represent the older assemblage; it underlies much of the western two-thirds of the quadrangle and forms part of a major Jurassic batholith that occupies large areas of the Bullion Mountains. Many of these rocks are included within the Bullion Mountains Intrusive Suite defined by Howard (2002). The most widespread unit is porphyritic granite and quartz monzonite that is correlated to the Virginia Dale Quartz Monzonite (Jbv) defined in ranges to the south of the quadrangle. Other rock units (Jbq, Jbpm, Jbe, Jbep) in the intrusive suite exhibit lithologic similarities to this unit and are likely to be similar in age and genetically related. They range in composition from granite to diorite (fig. 4). Other plutonic to volcanic or hypabyssal rock units (Jac, Ja, Jqd, Jvh) may be of similar Jurassic age. Mapping the contacts between these units was aided by study of Landsat images, aerial photographs, and an aeromagnetic map (U.S. Geological Survey, 1981). Bleached and albitized hypabyssal rocks were mapped as the hypabyssal quartz monzonite of Cleghorn Pass, based upon the presence of rare clinopyroxene and distinctive spectral signature on Landsat multispectral images. Jagiello (1991) called the body formed by this unit the Cleghorn Pass pluton, which he concluded is an important marker for establishing younger fault offsets.

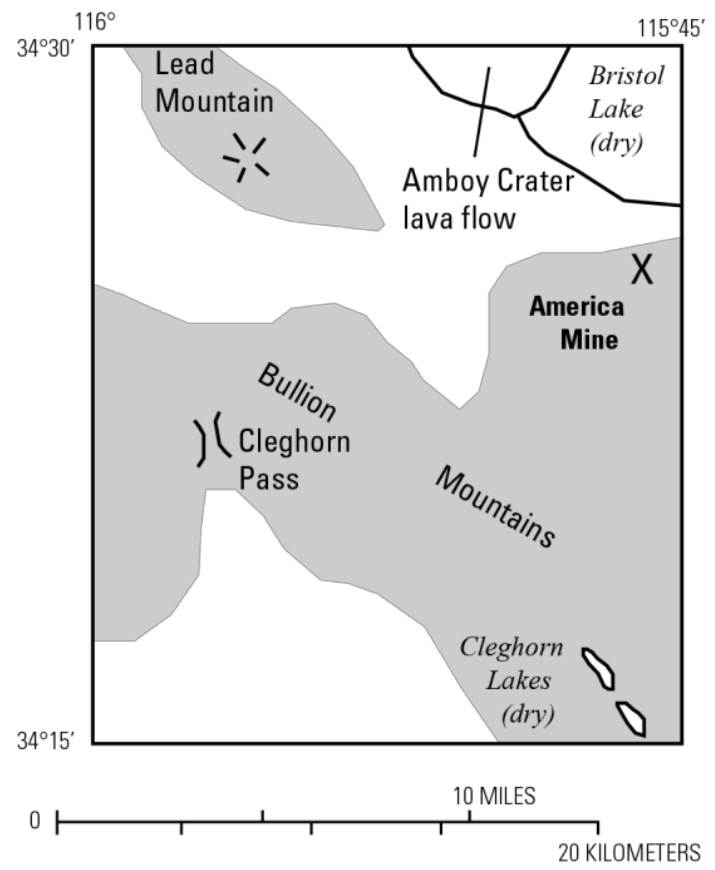

Figure 2. Map of mountains (shaded) and other geographic features in the Lead Mountain quadrangle.

The Jurassic plutonic rocks are cut by north-trending dikes including granite porphyry (Jgp) and mafic (Jmd) dikes of Jurassic age and felsite (Jf) and undivided (Jdu) dikes of Jurassic(?) age. At least 
some of these dikes probably correlate with the Independence dike swarm of Late Jurassic age studied by Karish and others (1987) and James (1989) farther west in the Mojave Desert (Hopson and others, 2008). The granite porphyry dikes (Jgp) have a finer-grained groundmass but otherwise lithologically resemble the Virginia Dale Quartz Monzonite that they intrude.

Cretaceous batholithic rocks represent a younger plutonic suite, the Coxcomb Intrusive Suite. The Sheep Hole Pass Granite of Late Cretaceous age is part of the Cadiz Valley batholith (John, 1981), which crops out widely in areas to the east of the quadrangle (Howard and John, 1984; Howard, 2002). The Sheep Hole Pass Granite is easily distinguished from the Jurassic rocks by its light color, the presence of abundant muscovite, and the lack of any metamorphic recrystallization. Granodiorite (Kcg) and porphyritic granite $(\mathrm{Kcpg})$ share these features of the Sheep Hole Pass Granite (except for muscovite) and are similar to other parts of the Cadiz Valley batholith; thus, they are also assigned a Late Cretaceous age.

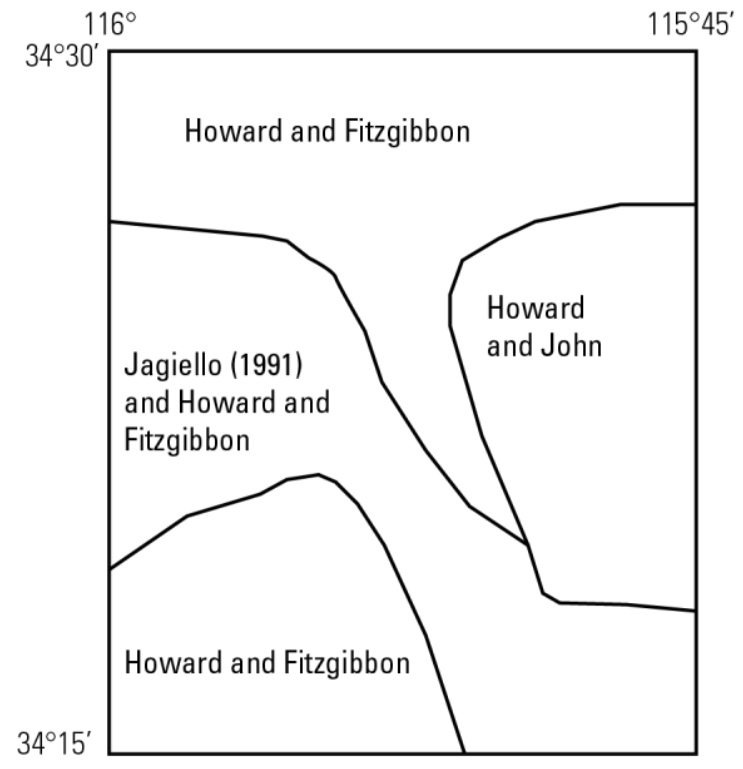

Figure 3. Index map of the Lead Mountain quadrangle showing areas of geologic mapping responsibility.

Surrounding the Sheep Hole Pass pluton is a contact aureole (patterned on the map) at least $2 \mathrm{~km}$ wide in which Jurassic and older rocks are foliated and show evidence of extensive metamorphic recrystallization. A yet-wider thermal aurole defined by cooling ages encompasses most of the area of the quadrangle. The presence of this cooling-age aureole is suggested by biotite ages determined by J.K. Nakata (written commun., 1986, 1987) using the potassium-argon (K-Ar) method for three widespread localities in the quadrangle: rock samples from the Virginia Dale Quartz Monzonite (Jbv) from sites 10 $\mathrm{km}$ southeast of Cleghorn Pass and $5 \mathrm{~km}$ northwest of Cleghorn Pass and a rock sample from the granite porphyry dikes (Jgp) unit $7 \mathrm{~km}$ southwest of Cleghorn Pass. All three yielded ages of 69 to $71 \mathrm{Ma}$, approximately the intrusive age of rocks dated in the Cadiz Valley batholith southeast of the quadrangle. The apparent ages can be interpreted to reflect resetting by heating and cooling of the Jurassic rocks through the closure temperature for Ar in biotite (approximately $300^{\circ} \mathrm{C}$ ) in Late Cretaceous time when the Cadiz Valley batholith was emplaced. A southwestern outer limit to the area of Late Cretaceous cooling ages is defined by two sites a few kilometers southwest and south of the quadrangle, where rocks from the Virginia Dale Quartz Monzonite yielded biotite K-Ar ages of 163 and 155 Ma (Miller and Morton, 1980; Calzia and Morton, 1980). 
The record of Cenozoic magmatism begins in the early Miocene and continues into late Pleistocene or Holocene time. Early Miocene dacitic rocks (including related andesite and rhyolite) form the eastern Bullion dike swarm in the eastern part of the quadrangle and a voluminous volcanicintrusive complex at Lead Mountain in the northwestern part of the quadrangle. The eastern Bullion dike swarm is a dense swarm of northeast-dipping dikes (Tdd). The dacitic complex at Lead Mountain consists of a thick (thicker than $1 \mathrm{~km}$ ) pile more than $5 \mathrm{~km}$ wide of volcanic (Tdv) and epiclastic rocks (Tdvc) intruded by a stock (Tdi). The volcanic and volcaniclastic rocks in this pile dip from $10^{\circ}$ to $80^{\circ}$ and are more faulted than the dacitic intrusive rocks. This volcanic-intrusive complex at Lead Mountain is interpreted as the remnants of an early Miocene volcano consisting of a thick accumulation of volcanic and volcaniclastic rocks cored by a central dacite intrusion. The volcanic rocks (Tdv) unit yielded early Miocene ages, 20 to $21 \mathrm{Ma}$. Amygdaloidal basalt (Tab) intrudes the volcaniclastic rocks (Tdvc) of the complex and is in turn intruded by the stock assigned to the intrusive rocks (Tdi) unit. Arkosic beds are contained within the amygdaloidal basalt (Tab) and intrusive rocks (Tdi) units and add further definition to a sequential record of early Miocene events in the area of the volcano. This record indicates successive emplacement or depositon of dacite volcaniclastic rocks and lavas (Tdvc), arkose (Tab), basalt (Tab), more arkose (inclusions in Tdi), and intrusive dacite (Tdi). The dacite and the amygdaloidal basalt record part of a widespread igneous flareup in the region occurring in the early Miocene (Armstrong and Higgins, 1973; Hazlett, 1990; Sherrod and Nielson, 1993).

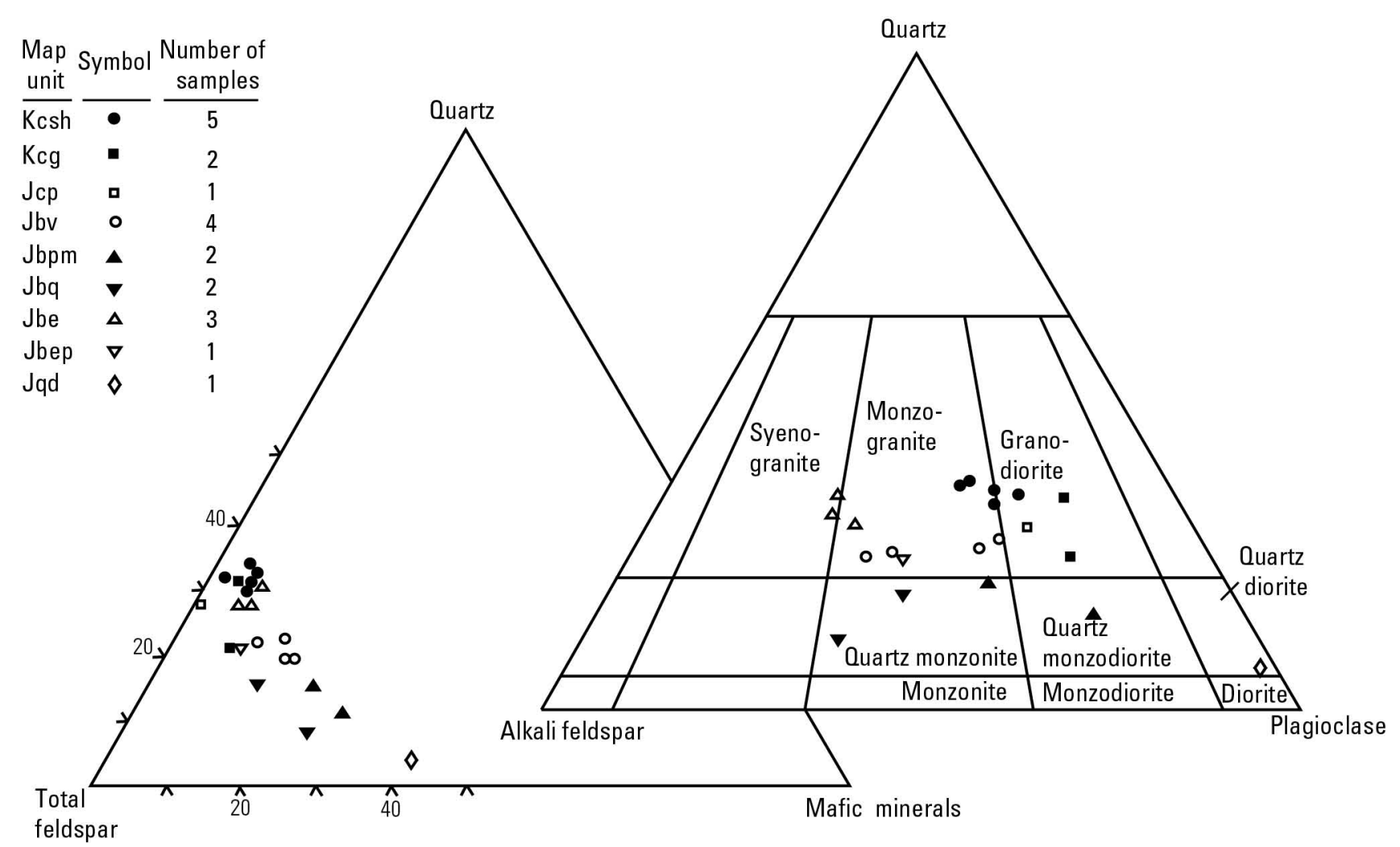

Figure 4. Modal mineral proportions in some plutonic rock units. Classification of plutonic rock names is after Streckeisen (1973).

Erosion of the early Miocene volcano is recorded by a unit of alluvial conglomerate (Tc) about $500 \mathrm{~m}$ thick. This unit unconformably overlies the volcanic-intrusive complex at Lead Mountain and is 
assigned a Miocene and (or) Pliocene age because it is in turn overlain by the basalt of Deadman Lake volcanic field (Tbl, Tblc, Tbld) of Pliocene age.

This basalt is part of a field of cones and flows that crops out mainly to the west and north of the quadrangle and is distinguished by the presence of mantle-derived xenoliths (Wilshire and others, 1988). A Pliocene age for the volcanic field is suggested by correlation of the field with the Dish Hill cinder cone $15 \mathrm{~km}$ north of the quadrangle (fig. 1), which is dated at $2 \mathrm{Ma}$ (Wilshire and Nielson-Pike, 1986).

Continued basaltic volcanism resulted in two Quaternary basalt flows, which are present in the northern part of the quadrangle. The basalt of Lead Mountain (Qbl, Qblc) was dated by whole-rock KAr at 0.36 $\pm 0.04 \mathrm{Ma}$ (J.K. Nakata, written commun., 1985) and so is late Pleistocene in age. Abundant prehistoric petroglyphs decorate the flow's eroded south edge. The basalt of Amboy forms the Amboy Crater lava flow and is late Pleistocene or Holocene in age. This flow may be onlapped by playa deposits as much as 10 to $15 \mathrm{~m}$ thick if its base below the low east margin of the flow is really $15 \mathrm{~m}$ deep, as was indicated by a log of cuttings from a drill hole $2 \mathrm{~km}$ northeast of the quadrangle (Rosen, 1989, 1991). The flow vented from Amboy Crater, a cinder cone $5 \mathrm{~km}$ north of the quadrangle that is a distinctive landmark for travelers on historic U.S. Route 66.

Quaternary sedimentation occurred in broad alluvial fans that surround the mountains in the quadrangle and in playas (dry lakes) that occupy the basin centers. Drilling of sediments at Bristol Lake playa in areas to the east and northeast of the quadrangle provided evidence that playa environments have persisted there for more than 3.7 m.y. (Rosen, 1989, 1991). The alluvial-fan piedmont sedimentary deposits are divided into subunits. The oldest alluvium (Qo) unit is correlated with Pleistocene deposits 10 to $15 \mathrm{~km}$ south of the quadrangle near Twentynine Palms, and it has been broken and tilted by faulting. Overlying sedimentary breccia (Qbr) was likely formed by landsliding from a mountain front and perhaps was seismically triggered. In striking contrast to these coarse deposits is a sandstone (Qss) unit, which indicates a low-energy environment of deposition, present locally at the foot of the steep mountain front. A younger unit of older alluvium (Qoa) is undeformed. Younger alluvium (Qya) assigned a Holocene age veneers wide areas in the quadrangle, and youngest alluvium (Qy) is mapped along the most active drainages.

\section{Cenozoic Structure}

Early Miocene tectonic extension in the Mojave extensional belt is centered west and northwest of the quadrangle (Dokka, 1989). The eastern Bullion dike swarm in the quadrangle likely tilted to its northeast dips from inferred originally vertical initial orientations, as part of this extensional episode. Farther west in the Mojave extensional belt, tilting occurred between 22 and 17 Ma (Dokka, 1989), but the timing and amount of tilting in the Lead Mountain quadrangle is poorly constrained.

The regional early Miocene extension may be responsible also for steep northeast dips of early

Miocene beds that are measured on the north flank of Lead Mountain; or those dips instead may relate to early Miocene volcanism, or to Miocene to Quaternary deformation along the east branch of the Ludlow Fault Zone. A north-northeast strike for a rare feeder dike (Tbld) that is associated with a vent for the basalt of Deadman Lake volcanic field suggests this direction of greatest horizontal compressive stress in the late Pliocene.

Northwest- and east-striking faults in the quadrangle are included as part of the eastern California shear zone, which records late Neogene strike-slip motions in the boundary zone between the Pacific and North American plates (Dibblee, 1961; Dokka and Travis, 1990; Richard, 1992). This faulting likely blocked out most of the present physiographic features in the quadrangle. Faults of east strike in the eastern California shear zone are mostly sinistral, but Jagiello and others (1992) suggested 
2.3 to $5 \mathrm{~km}$ of dextral separation for the east-northeast-striking Segundo Fault. That fault is the best exposed of a family of parallel faults and faults inferred from aeromagnetic gradients.

Northwest-striking faults are the more prominent features in the eastern California shear zone. Jagiello and others (1992) proposed $16 \mathrm{~km}$ of dextral separation along the northwest-striking Cleghorn Pass Fault Zone to explain their correlation of their Cleghorn Pass pluton and Segundo Fault with similar features just south of the eastern part of the quadrangle. Dextral separation on the northweststriking Cleghorn Lakes Fault Zone was estimated at 6 to $14 \mathrm{~km}$ by Jagiello and others (1992) and 2 to 3 $\mathrm{km}$ by Howard and Miller (1992). A dextral separation of at least $3 \mathrm{~km}$ on the northern part of this fault zone would explain the distribution of the metamorphic aureole mapped around the Sheep Hole Pass pluton. Restoration of from 5 to $20 \mathrm{~km}$ of dextral separation on the fault zone, and its possible extension to the Ludlow Fault Zone (east branch), would restore a clast assemblage in the lower part of the alluvial conglomerate (Tc) unit, southeast of Lead Mountain, close to matching source rocks in the eastern Bullion Mountains south of the America Mine.

A Pleistocene age for last motion along both the northwest-striking Cleghorn Pass and Cleghorn Lakes Fault Zones is indicated by faulting of the oldest alluvium (Qo) unit (Pleistocene in age) and lack of deformation of the older alluvium (Qoa) unit (late Pleistocene in age) (Howard and Miller, 1992; Jagiello and others, 1992).

The northwest-striking Ludlow Fault Zone deforms early Pleistocene alluvium $5 \mathrm{~km}$ northwest of the quadrangle (Dibblee, 1967a; Howard and Miller, 1992). Within the quadrangle, the east branch of this fault is covered by, and therefore predates, the older alluvium (Qoa) unit containing clasts derived from the $0.36 \pm 0.04-\mathrm{Ma}$ basalt of Lead Mountain $(\mathrm{Qbl})$. Even though no faulting is recognized in the quadrangle younger in age than the older alluvium (Qoa) unit, the occurrence of moderate seismicity (Goter, 1992) suggests that blind fault activity continues to the present.

\section{Acknowledgments}

Robert Simpson helped with interpretation of aeromagnetic data. John Nakata dated rocks using the K-Ar method. Jonathan Matti and Victoria Todd provided technical reviews of the map and report. J.R. LeCompte reviewed geologic names. We also thank Geoffry Phelps, Douglas Hirschberg, and Pamela Cosette for skillfully applying Geographic Information Systems to the map.

\section{DESCRIPTION OF MAP UNITS}

Piedmont sedimentary deposits - Poorly sorted, poorly stratified alluvial-fan deposits deposited by sheet floods and debris flows and sedimentary breccia inferred to be landslide deposits. Subunits gradational and boundaries not necessarily time-correlative

Qy Youngest alluvium (Holocene) - Sand and gravel in active washes

Qya Younger alluvium (Holocene) - Sandy gravel in alluvial fans. Some older parts of unit have surface of poorly developed desert pavement. Overlies older alluvium (Qoa) unit

Qoa Older alluvium (Pleistocene) - Sandy gravel in alluvial fans. Surface generally characterized by dark pavement of varnished stones. Light colored where source rocks are felsic granitoids. Dissected by erosion in some areas. Includes alluvium that contains clasts derived from basalt of Lead Mountain 
(Qbl), dated at $0.36 \pm 0.04 \mathrm{Ma}$. Overlies oldest alluvium (Qo) unit and underlies the young alluvium (Qya) unit. Age is late Pleistocene, based on contained clasts derived from late Pleistocene basalt and on the presence of well-developed desert pavement inferred to be pre-Holocene in age

Sedimentary breccia (Pleistocene) - Breccia composed of boulders (as large as $4 \mathrm{~m}$ across) derived from Virginia Dale Quartz Monzonite (Jbv). Present 3 $\mathrm{km}$ southeast of Cleghorn Pass. Gradationally overlies dipping oldest alluvium (Qo) unit. Interpreted as a landslide deposit

Qo

Oldest alluvium (Pleistocene) - Sandy gravel or conglomerate derived from nearby mountains. Section $3 \mathrm{~km}$ southeast of Cleghorn Pass (sec. 23, T. 3 N., R. 10 E.) consists of basal coarse arkosic sand and overlying boulder conglomerate with boulders as large as $1 \mathrm{~m}$; section gradationally overlain by sedimentary breccia (unit Qbr). Exposures $2 \mathrm{~km}$ north of Cleghorn Lakes (SE1/4 sec. 35, T.3 N., R.11 E.), in southeastern part of quadrangle, contain clasts derived from the Sheep Hole Mountains Granodiorite (which crops out southeast of the map area), as well as clasts derived from dacitic dikes, gneiss, metamorphosed parts of quartz monzonite unit and Virginia Dale Quartz Monzonite, vein quartz, pegmatite, and Sheep Hole Pass Granite. Unit is commonly faulted, tilted, and dissected. Overlain by older alluvium (Qoa) unit. Age is Pleistocene based on correlation with similar deposits in adjacent Valley Mountain quadrangle (Howard and others, 1995) that contain Rancholabrean fauna (Bassett and Kupfer, 1964; Bacheller, 1978) and an ash bed correlated by Bacheller (1978) with the 0.7-Ma Bishop Tuff

Qss Sandstone (Pleistocene) - Massive, friable arkosic sandstone and mudstone. Present adjacent to steep mountain front $4 \mathrm{~km}$ west of Cleghorn Lakes in southeast part of quadrangle

\section{Playa deposits}

Qps Playa-floor deposits (Holocene) - Silt, clay, halite, and gypsum associated with brine

Qpb

Qba Basalt of Amboy (Holocene or Pleistocene) - Olivine basalt. Forms pahoehoe lava flow known as Amboy Crater lava flow. Lava surface forms were described by Parker (1963). $\mathrm{SiO}_{2}$ contents reported for this flow range from 47 to 50 percent (Glazner and others, 1991). Onlapped by playa-floor deposits (Qps). An apparent thickness of $15 \mathrm{~m}$ of basalt at east margin of flow, adjacent to playa floor of Bristol Lake, was logged from drill-hole cuttings in CAES 1 test well, $2 \mathrm{~km}$ northeast of quadrangle (Rosen, 1989, 1991)

Qbl Basalt of Lead Mountain (Pleistocene) - Olivine basalt. Forms aa lava flow. Age $0.36 \pm 0.04 \mathrm{Ma}$ (late Pleistocene) by K-Ar dating of whole rock (J.K. Nakata, written commun., 1985). $\mathrm{SiO}_{2}$ content 48 percent (one sample). Overlies unmapped, undeformed alluvial conglomerate that probably correlates with either the oldest alluvium (Qo) or older alluvium (Qoa) units

Qblc Basalt cinders-Forms undissected cinder cone 
Tbl Basalt of Deadman Lake volcanic field (Pliocene) - Olivine basalt flows. Contains olivine, spinel, and clinopyroxene phenocrysts and ultramafic xenoliths. Forms part of Deadman Lake volcanic field, which contains many cones and flows in adjacent Deadman Lake quadrangle (fig. 3), where Wilshire and others (1988) determined $\mathrm{SiO}_{2}$ contents of 44 to 46 percent for the basalt. Overlies and probably interfingers with horizontally bedded rocks assigned to uppermost part of alluvial conglomerate (Tc) unit. Age may be similar to 2Ma basalt of Dish Hill $15 \mathrm{~km}$ to north (fig. 1; Wilshire and Nielson-Pike, 1986). Dish Hill unit is assigned to Deadman Lake volcanic field, based on aligned cones and aeromagnetic highs (probably buried cones) that lie between and appear to connect Dish Hill to the Deadman Lake field

Tblc Basalt cinders and agglutinate-Present at source vents

Tbld Basalt dike - Cuts alluvial conglomerate (Tc) unit. Mapped by Schafer and others (1959b)

Tc Alluvial conglomerate (Pliocene and (or) Miocene) - West of Lead Mountain, consists of horizontal, well-bedded and crossbedded, fluvial sand and gravel. Southeast of Lead Mountain, consists of about $500 \mathrm{~m}$ of south-dipping, moderately sorted, and planar-bedded (best displayed in lower part of unit) pebble, cobble, and boulder conglomerate and sandstone, which rest with angular unconformity on an irregular erosion surface cut into dacitic rocks; clasts consist of dacite, quartz monzonite, (in lower part of unit) muscovite granite, and rare wollastonite marble, which all match lithologically and probably were derived from bedrock units exposed in eastern part of Bullion Mountains in eastern part of quadrangle; restoration of dextral slip along east branch of Ludlow Fault Zone would place conglomerate closer to this source

Tbd Basalt dike (Miocene)_-Mapped in southeastern Bullion Mountains (sec. 31, T. 3 N., R. 11 E). Unmapped basalt dikes are present on hill 2830, secs. 2 and 3, T. 4 N., R. 11 E., in northeastern Bullion Mountains

Td Dacitic rocks (Miocene) - Composition ranges from rhyolite to andesite but is predominantly dacite; phenocrysts are abundant plagioclase, common biotite and hornblende, and rare quartz (rounded, embayed) and sanidine. Age is early Miocene based on K-Ar dating of volcanic rocks (Tdv) subunit. As mapped, includes volcanic-clast breccia in eastern Bullion Mountains (sec. 11, T. 3 N., R. 11 E.) that possibly is a landslide deposit postdating main unit. Locally, divided by generalized boundaries

Tdi

Intrusive dacite - Massive stock and satellite dikes at Lead Mountain. Greenish gray. Plagioclase and mafic minerals altered. $\mathrm{SiO}_{2}$ content (one sample) 66 percent. Contains inclusions of arkosic sandstone. Intrudes volcanic rocks (Tdv) and volcaniclastic rocks (Tdvc) subunits, amygdaloidal basalt (Tab) unit, and Virginia Dale Quartz Monzonite (Jbv). Contains small inclusions of pebbly arkosic sandstone that contain clasts derived from amgdaloidal basalt (Tab). Less faulted than adjacent volcanic rocks (Tdv) subunit. Parts of eastern Bullion dike swarm are included in this unit where dikes are mappably thick or in locally dense swarms

Tdd Dikes of the eastern Bullion dike swarm-Dike swarm forms about 10 to 20 percent of rocks in Bullion Mountains east of Cleghorn Lakes Fault. Massive 
Tdv

Tdve

Tab

Kcsh

$\mathrm{Kcg}$

Kcpg

Jmd

to jointed outcrops weather pale greenish to pale violet gray. Plagioclase and mafic minerals (biotite, sparse hornblende) altered. Quartz phenocrysts present in some dikes. Rare dikes contain hornblende in glomerocrysts. One analyzed dike, 68 percent $\mathrm{SiO}_{2}$. Most dikes dip at moderate angles to northeast. Thick dikes and dense swarms of dikes 3 to $10 \mathrm{~km}$ north of Cleghorn Lakes are locally mapped as intrusive rocks (Tdi) unit

Volcanic rocks-Flows (including vitrophyres), flow breccias, and tuffs. Varicolored (red, yellow, green, white, gray, black). Three analyzed samples contain 68,69 , and 74 percent $\mathrm{SiO}_{2}$. K-Ar ages $20.1 \pm 1.0 \mathrm{Ma}$ (biotite) and $20.8 \pm 0.5 \mathrm{Ma}$ (hornblende) for two samples (J.K. Nakata, written commun., 1985; Howard, 1993)

Volcaniclastic rocks - Poorly sorted tuff, agglomerate, diamictite (probably lahar deposits), rare dacitic or andesitic lava flows, and immature volcaniclastic sandstone. Exposed thickness of about $1 \mathrm{~km}$ on north side of Lead Mountain. Two lava flows occur in this north-dipping section, one near middle and second at top of exposed section. Unit rests on shattered porphyritic quartz monzonite, which may be landslide megabreccia or faulted Virginia Dale Quartz Monzonite

Amygdaloidal basalt (Miocene) - Black, dense, felted-textured to hyalopilitic basalt and olivine basalt containing abundant calcite (and local chalcedony) amygdules. Probably largely intrusive. Intrudes volcaniclastic rocks (Tdvc) unit and is intruded by dikes of intrusive rocks (Tdi) unit. Unit locally contains granite-clast arkosic sandstone intruded by and locally forming pepperite-like mixtures with basalt

\section{Coxcomb Intrusive Suite}

Sheep Hole Pass Granite (Late Cretaceous) - White, medium-grained, equigranular biotite-muscovite leucomonzogranite (fig. 4). Plagioclase shows oscillatory zoning. Locally includes biotite granodiorite. Pluton (structural body) formed by this unit is called here the Sheep Hole Pass pluton. Intrudes Virginia Dale Quartz Monzonite (Jbv), granite east of Cleghorn Pass (Jbe), and quartz monzonite (Jbq) unit. Age is Late Cretaceous, based on K-Ar ages (interpreted here as cooling ages) of $69 \mathrm{Ma}$ on biotite and $69 \mathrm{Ma}$ on muscovite in Sheep Hole Pass southeast of quadrangle (Armstrong and Suppe, 1973; Calzia and Morton, 1980) and on intrusive relations that indicate that these rocks are younger than most other parts of the approximately 70-Ma Coxcomb Intrusive Suite (Howard and John, 1984; Howard, 2002)

Granodiorite (Late Cretaceous) - White to light-gray, fine- to medium-grained, equigranular sphene-biotite monzogranite and granodiorite. May grade into the Sheep Hole Pass Granite

Porphyritic granite (Late Cretaceous) - Small outcrop in Cleghorn Pass. White to light gray, medium-grained, porphyritic biotite granite. Phenocrysts of white K-feldspar as long as $2 \mathrm{~cm}$. Cuts adjacent Jurassic granitoids. Rocks previously called granite of southern Cleghorn Pass by Jagiello (1991)

Mafic dikes (Jurassic) - Dark-gray or greenish-gray microdiorite dikes with chilled borders. Intrudes Virginia Dale Quartz Monzonite (Jbv). Probably part of Independence dike swarm of Late Jurassic age described by Chen and Moore 
(1979), James (1989), Karish and others (1987), and Hopson and others (2008; Howard, 2002)

Jgp Granite porphyry dikes (Jurassic) —Contain biotite and lavender, euhedral, locally plagioclase-mantled phenocrysts of K-feldspar 1 to $2 \mathrm{~cm}$ across. The $10-\mathrm{m}-$ thick dike that cuts the Virginia Dale Quartz Monzonite in sec. 36, T. 3 N., R. $9 \mathrm{E}$ has K-feldspar phenocrysts 2 to $3 \mathrm{~cm}$ across and mafic inclusions in dike center and chilled, flow-banded aphyric margins, indicating that phenocrysts were flow-sorted; $\mathrm{SiO}_{2}$ content (one sample) 66 percent. Intrudes Virginia Dale Quartz Monzonite (Jbv)

Jf Felsite dikes (Jurassic?) - Dark-gray to purplish or light-colored dikes. Contain phenocrysts of feldspar, including sanidine, altered mafic minerals, and abundant quartz. Intrudes quartz monzonite (Jbq) unit

Jdu Dikes, undivided (Jurassic?) - Mostly mapped from aerial photographs. Unit includes biotite granite porphyry dikes with 2-cm-wide phenocrysts of plagioclase-rimmed perthite

Jcp Hypabyssal quartz monzonite of Cleghorn Pass (Jurassic) — Whitish to greenish, altered, bleached, hypabyssal quartz monzonite, monzonite, and granite. Weathers orange to light brown. Consists of feldspar (including very rare pink K-feldspar phenocrysts), quartz, and xenoblastic sphene, 2 to 15 percent clinopyroxene (rarely preserved), and secondary epidote, chlorite, colorless clinoamphibole, and calcite. Relict porphyritic textures indicate hypabyssal emplacement. Generally albitized, yielding high contents of $\mathrm{Na}_{2} \mathrm{O}$ and low contents of $\mathrm{K}_{2} \mathrm{O}$. $\mathrm{SiO}_{2}$ contents of 4 analyzed samples are 60, 67, 69, and 70 percent. Intrudes Virginia Dale Quartz Monzonite (Jbv) and quartz monzonite (Jbq) unit. Body formed by the unit was called Cleghorn Pass pluton by Jagiello (1991) and Jagiello and others (1992)

\section{Bullion Mountains Intrusive Suite}

Jbv Virginia Dale Quartz Monzonite (Jurassic)-Medium-grained, porphyritic, sphene-biotite monzogranite and sphene-hornblende-biotite quartz monzonite. Weathers to rough, rounded, bouldery outcrops. Mafic mineral content 11 to 18 percent. K-feldspar phenocrysts generally lavender or purplish, 1 to $2.5 \mathrm{~cm}$ across, equant, subrounded, and rimmed by albite. Common round mafic clots and enclaves (including mafic quartz diorite) 1 to $10 \mathrm{~cm}$ across; some contain phenocrysts identical to those of host rock. In west-central part of quadrangle, matrix has granophyric texture. Matrix greenish due to epidote \pm chlorite alteration. Highly altered by calcite and clay minerals on Lead Mountain. Xenocrystic textures present in metamorphosed zone in eastern part of quadrangle. $\mathrm{SiO}_{2}$ content of three monzogranite samples each 67 percent. Cut by aplite dikes. Correlated with unit mapped as biotite quartz monzonite (bqm) by Dibblee (1967b) in adjacent Deadman Lake quadrangle (fig. 1). Provisionally assigned to Virginia Dale Quartz Monzonite mapped south of the quadrangle (Howard and others, 1995), where K-Ar and U-Pb dating established an intrusive age of approximately 160 to $167 \mathrm{Ma}$ (for example, Barth and others, 2008)

Jbpm Mafic porphyritic quartz monzonite (Jurassic)—Quartz monzonite, quartz monzodiorite, quartz diorite, and diorite. Mafic minerals (hornblende, biotite, 
sphene, magnetite) composing 17 percent or more of rock form distinctive clots. White to lavender K-feldspar phenocrysts 1 to $2 \mathrm{~cm}$ across. Abundant mafic enclaves $5 \mathrm{~cm}$ to $3 \mathrm{~m}$ across vary greatly in abundance; rock becomes gradationally dioritic where enclaves dominate or constitute all of rock. Some enclaves rimmed by zones rich in K-feldspar phenocrysts, and some enclaves contain K-feldspar phenocrysts. Dioritic dikes and quartz monzonite show mutually crosscutting relationships. Intruded by unmapped nonporphyritic quartz monzonite (probably correlative with quartz monzonite unit, Jbq). Underlies an aeromagnetic high. Boundaries mapped largely from Landsat multispectral imagery. A Jurassic age is inferred because felsic parts of unit resemble Virginia Dale Quartz Monzonite

Quartz monzonite (Jurassic) - Gray, medium-grained, equigranular biotite quartz monzonite and monzogranite. Weathers to blocky, rectangular outcrops. Mafic mineral content (biotite, sphene, magnetite, and secondary chlorite and epidote) 5 to 25 percent. Rare small phenocrysts of plagioclase and lavender perthite. Mafic enclaves present. In metamorphosed zone shown by pattern in eastern part of quadrangle, texture is xenocrystic to foliated lepidoblastic, and rock is commonly foliated. Cut by aplite dikes. A Jurassic age is inferred because similar rocks in nearby Pinto Mountains show mutual crosscutting relations with Virginia Dale Quartz Monzonite

Granite east of Cleghorn Pass (Jurassic) — Light-colored, medium-grained biotite monzogranite, leucomonzogranite, and syenogranite. Mafic mineral content 2 to 8 percent (biotite, sphene, moderately rare hornblende, magnetite; secondary chlorite, muscovite, and epidote). Rare white K-feldspar phenocrysts 1 to $2 \mathrm{~cm}$ across. Feldspars commonly perthitic. $\mathrm{SiO}_{2}$ content of two samples each 71 percent. In exposures west of Cleghorn Pass Fault in Cleghorn Pass, contains no hornblende or perthite and is lighter in color than much of the unit due to low content of disseminated biotite. A Jurassic age is inferred because porphyritic facies (Jbep) resembles the Virginia Dale Quartz Monzonite

Porphyritic facies - Biotite monzogranite containing rounded, plagioclaserimmed, K-feldspar phenocrysts 2 to $3 \mathrm{~cm}$ across and rounded plagioclase phenocrysts as wide as $1 \mathrm{~cm}$. $\mathrm{SiO}_{2}$ content (one sample) 69 percent. Closely resembles Virginia Dale Quartz Monzonite. Intruded by abundant unmapped aplite dikes

Jqd Quartz diorite (Jurassic) - Dark-colored, hornblende-biotite quartz diorite. Mafic minerals (biotite, hornblende, brown sphene, magnetite, secondary epidote) clotted. $\mathrm{SiO}_{2}$ content (one sample) 54 percent. A Jurassic age is inferred based on resemblance to similar rocks in Pinto Mountains dated as Jurassic by uranium-lead method on zircon (Barth and others, 2008)

Jac Altered granite near Cleghorn Lakes (Jurassic) - South and west of southern end of the Cleghorn Lakes. Consists of light-gray, silicified granite; mafic mineral content (magnetite, biotite, secondary chlorite) about 5 percent; feldspar perthitic; syenogranite composition may reflect potassium metasomatism

Ja Altered granite (Jurassic) - Bleached monzogranite exposed at southern margin of quadrangle near long $115^{\circ} 50^{\prime} \mathrm{W}$., and 1 and $5 \mathrm{~km}$ northwest of Cleghorn Pass 
Jvh Metavolcanic or hypabyssal rocks (Jurassic)—Rhyolitic rocks. Cut by unmapped dikes of the quartz monzonite ( $\mathrm{Jbq}$ ) unit. A Jurassic age is inferred because of broad lithologic resemblance to Dale Lake Volcanics (Howard, 2002)

Mzs Metasedimentary gneiss of Sheep Hole Mountains (Mesozoic(?), protolithic age) - Hornblende-epidote gneiss, schist containing green mica, amphibolite, and magnetite-bearing quartzofeldspathic gneiss. Correlated with a unit of gneiss and calcsilicate rocks in Sheep Hole Mountains (Howard and John, 1984). Present near marble ( $\mathrm{Pzm})$ unit. Unmapped layered hornblende-epidote gneiss that may relate to unit is associated with metavolcanic or hypabyssal rocks (Jvh) unit in southeastern part of quadrangle. Southeast of quadrangle, in Sheep Hole Mountains, unit forms a screen between granitoids of the Coxcomb Intrusive Suite of Late Cretaceous age and Virginia Dale Quartz Monzonite of Jurassic age (Howard and John, 1984; Howard, 2002). An early Mesozoic(?) (Triassic or Jurassic) protolithic age is assigned, because unit (1) does not much resemble known Proterozoic or Paleozoic units, (2) is associated with marble ( $\mathrm{Pzm})$ assigned a Paleozoic(?) protolithic age and with metavolcanic or hypabyssal rocks (Jvh) assigned a Jurassic age, and (3) contains lithologic assemblages that broadly resemble and could be in part equivalent to Mesozoic units such as McCoy Mountains Formation of Miller (1944), Buckskin Formation of Reynolds and Spencer (1989), Moenkopi Formation, and Fairview Valley Formation (Bowen, 1954; see also Dibblee, 1967c) and overlying quartzite (Miller, 1981; Walker, 1988)

Pzm Marble (Paleozoic(?), protolithic age) - White calcitic marble and diopside-bearing wollastonite rocks. Resembles metamorphosed Bird Spring Formation (Pennsylvanian and Permian). Close association with metasedimentary gneiss of Sheep Hole Mountains suggests alternative possibility of a Mesozoic protolithic age

Yag Augen gneiss (Mesoproterozoic(?), protolithic age)-Coarse-grained, quartz-rich, granite augen gneiss. K-feldspar augen are pink. Resembles and is correlated to augen gneiss of northern Calumet Mountains (Howard and John, 1984; Howard, 2002), which is tenatively correlated lithologically with granite in Marble Mountains (fig. 1) that was dated by uranium-lead method on zircon as $1.4 \mathrm{Ga}$ in age (Silver and McKinney, 1973)

\section{References Cited}

Anctil, R.J., and Schafer, Max, 1958, Geology and mineral resources of Township 2 North, Ranges 11 and 12 East, San Bernardino Base and Meridian, San Bernardino County, California: Albuquerque, N.M., Santa Fe Pacific Mining, Inc., unpublished map and report, scale 1:24,000.

Armstrong, R.L., and Higgins, R.E., 1973, K-Ar dating of the beginning of Tertiary volcanism in the Mojave Desert, California: Geological Society of America Bulletin, v. 84, p. 1095-1100.

Armstrong, R.L., and Suppe, J., 1973, Potassium-argon geochronometry of Mesozoic igneous rocks in Nevada, Utah, and southern California: Geological Society of America Bulletin, v. 84, p. 1375-1392. 
Bacheller, John, III, 1978, Quaternary geology of the Mojave Desert-Eastern Transverse Ranges boundary in the vicinity of Twentynine Palms, California: Los Angeles, University of California, M.S. thesis, $157 \mathrm{p}$.

Barth, A.P., Wooden, J.L., Howard, K.A., and Richards, J.L., 2008, Late Jurassic plutonism in the southwest U.S. Cordillera, in Wright, J.E. and Shervais, J., eds., Ophiolite, arcs, and batholiths: Geological Society of America Special Paper 438, p. 379-396, doi:10.1130/2008.2438(13).

Bassett, A.M., and Kupfer, D.H., 1964, A geologic reconnaissance in the southeastern Mojave Desert, California: California Division of Mines and Geology, Special Report 83, 43 p.

Bedford, D.R., Miller, D.M., and Phelps, G.A., 2010, Surficial geologic map of the Amboy 30' x 60' quadrangle, San Bernardino County, California: U.S. Geological Survey, Scientific Investigations Map SIM-3109, scale 1:100000. (Available at http://pubs.usgs.gov/sim/3109/.)

Bishop, C.C.,1964, Needles sheet: California Division of Mines and Geology, Geologic map of California, Olaf P. Jenkins Edition, scale 1:250,000.

Bonham, H.F., Jr., 1957, Geology and mineral resources of Township 3 North, Ranges 9 and 10 East, San Bernardino Base and Meridian, San Bernardino County, California: Albuquerque, N.M., Santa Fe Pacific Mining, Inc., unpublished map and report, scale 1:24,000.

Bowen, O.E., 1954, Geology and mineral deposits of the Barstow quadrangle, San Bernardino County, California: Division of Mines, California Department of Natural Resources Bulletin 165, 208 p.

Calzia, J.P., and Morton, J.L., 1980, Compilation of isotopic ages within the Needles $1^{\circ}$ by $2^{\circ}$ quadrangle, California and Arizona: U.S. Geological Survey Open-File Report 80-1303, scale $1: 250,000$.

Chen, J.H., and Moore, J.G., 1979, Late Jurassic Independence dike swarm in eastern California; Geology, v. 7, p. 129-133.

Cunningham, A.B., and Bonham, H.F., Jr., 1958, Geology and mineral resources of Township 4 North, Ranges 9 and 10 East, San Bernardino Base and Meridian, San Bernardino County, California: Albuquerque, N.M., Santa Fe Pacific Mining, Inc., unpublished map and report, scale 1:24,000.

Cunningham, A.B., Danehy, E.A., and Spurck, W.H., 1962, Geology and mineral resources of Township 4 North, Ranges 11 and 12 East, San Bernardino Base and Meridian, San Bernardino County, California: Albuquerque, N.M., Santa Fe Pacific Mining, Inc., unpublished map and report, scale $1: 24,000$.

Cunningham, A.B., Schafer, Max, and Anctil, R.J., 1958, Geology and mineral resources of Township 3 North, Ranges 11 and 12 East, San Bernardino Base and Meridian, San Bernardino County, California: Albuquerque, N.M., Santa Fe Pacific Mining, Inc., unpublished map and report, scale $1: 24,000$.

Dibblee, T.W., Jr., 1961, Evidence of strike-slip movement on northwest-trending faults in Mojave Desert, California, in Geological Survey Research, 1961: U.S. Geological Survey Professional Paper 424-B, p. 197-199.

Dibblee, T.W., Jr., 1967a, Geologic map of the Ludlow quadrangle, San Bernardino County, California: U.S. Geological Survey Miscellaneous Geologic Investigations Map I-477, scale 1:62,500.

Dibblee, T.W., Jr., 1967b, Geologic map of the Deadman Lake quadrangle, San Bernardino County, California: U.S. Geological Survey Miscellaneous Geologic Investigations Map I-488, scale 1:62,500.

Dibblee, T.W., Jr., 1967c, Areal geology of the western Mojave Desert, California: U.S. Geological Survey Professional Paper 522, 153 p. 
Dibblee, T.W., Jr., 1968, Geologic map of the Twentynine Palms quadrangle, San Bernardino and Riverside Counties, California: U.S. Geological Survey Miscellaneous Geologic Investigations Map I-561, scale 1:62,500.

Dokka, R.K., 1989, The Mojave extensional belt of southern California: Tectonics, v. 8, p. 363-390.

Dokka, R.K.. and Travis, C.J., 1990, Late Cenozoic strike-slip faulting in the Mojave Desert, California: Tectonics, v. 9, p. 311-340.

Durrell, C., 1953, Celestite deposits at Bristol Dry Lake, near Amboy, San Bernardino County, California, in Durrell, C., Geological investigations of strontium deposits in southern Calaifornia: California Division of Mines Special Reoport 32, p. 9-14.

Fife, D.L., 1985, War Eagle mine: California Geology, v. 38, p. 109-111.

Gale, H.S., 1951, Geology of the saline deposits, Bristol Dry Lake, San Bernardino County, California: California Division of Mines Special Report 13, 21 p.

Glazner, A.F., Farmer, G.L., Hughes, W.T., Wooden, J.L., and Pickthorn, William, 1991, Contamination of basaltic magma by mafic crust at Amboy and Pisgah craters, Mojave Desert, California: Journal of Geophysical Research, v. 96, p. 13,673-13,691.

Goter, S.K., 1992, Southern California earthquakes: U.S. Geological Survey Open-File Report 92-533, scale 1:375,000.

Gundry, R.R., 1992, Saline minerals extraction from southern Mojave Desert playas of California, in Reynolds, R.E., comp., Old Routes to the Colorado: Redlands, Calif., San Bernardino County Museum Association Special Publication 92-2, p. 65-70.

Hazlett, R.W., 1990, Extension-related Miocene volcanism in the Mopah Range volcanic field, southeastern California, in Anderson, J.L., ed., The nature and origin of Cordilleran magmatism: Geological Society of America Memoir 174, p. 133-145.

Hopson, R.F., Hillhouse, J.W., and Howard, K.A., 2008, Dike orientations in the Late Jurassic Independence dike swarm and implications for vertical axis tectonic rotations in eastern California, in Wright, J.E. and Shervais, J.W., eds., Ophiolite, arcs, and batholiths: Geological Society of America Special Paper 438, p. 481-498, doi:10.1130/2008.2438(17).

Howard, K.A., 1993, Cenozoic stratigraphy of the Lead Mountain and Valley Mountain areas, eastern Bullion Mountains, Calif., in Sherrod, D.R. and Nielson, J.E., eds., Tertiary stratigraphy of highly extended terranes, California, Arizona, and Nevada: U.S. Geological Survey Bulletin 2053, p. 95-97.

Howard, K.A., 2002, Geologic map of the Sheep Hole Mountains 30' x 60' quadrangle, San Bernardino and Riverside Counties, California: U.S. Geological Survey map MF-2344, scale 1:100,000, 2 sheets. (Available at http://pubs.usgs.gov/mf/2002/2344/.)

Howard, K.A., Bacheller, John, Fitzgibbon, T.T., Powell, R.E., and Allen, C.M., 2013, Geologic map of the Valley Mountain 15' quadrangle, San Bernardino and Riverside Counties, California: U.S. Geological Survey Map GQ-1767, scale 1:62,5000. (Availabe at http://pubs.usgs.gov/gq/1767/.)

Howard, K.A., and John, B.E., 1984, Geologic map of the Sheep Hole-Cadiz Wilderness Study Area (CDCA-305), San Bernardino County, California: U.S. Geological Survey Miscellaneous Field Studies Map 1615-A, scale 1:62,500.

Howard, K.A., and Miller, D.M., 1992, Late Cenozoic faulting at the boundary between the Mojave and Sonoran blocks, Bristol Lake area, California, in Richard, S.M., ed., Deformation associated with the Neogene eastern California shear zone, southeastern California and southwestern Arizona: Redlands, Calif., San Bernardino County Museums Special Publication 92-1, p. 37-47. 
Jachens, R.C., and Howard, K.A., 1992, Bristol Lake basin-A deep sedimentary basin along the Bristol-Danby trough, Mojave Desert, in Reynolds, R.E., comp., Old Routes to the Colorado: Redlands, Calif., San Bernardino County Museum Association Special Publication 92-2, p. 57-59.

Jagiello, K.J., 1991, Determination of horizontal separation on late Cenozoic strike-slip faults in the central Mojave Desert, southern California: Los Angeles, University of California, Ph.D. dissertation, 293 p.

Jagiello, Keith, Christie, J.M., and Blom, R.M., 1992, Horizontal separation of major late Cenozoic strike-slip faults in the Twenty-nine Palms region, Mojave Desert, California, in Richard, S.M., ed., Deformation associated with the Neogene eastern California shear zone, southeastern California and southwestern Arizona: Redlands, Calif., San Bernardino County Museum Special Publication 92-1, p. 48-53.

James, E.W., 1989, Southern extension of the Independence dike swarm of eastern California: Geology, v. 17, p. 587-590.

John, B.E., 1981, Reconnaissance study of Mesozoic plutonic rocks in the Mojave Desert region, in Howard, K.A., Carr, M.D., and Miller, D.M., eds., Tectonic framework of the Mojave and Sonoran Deserts, California and Arizona: U.S. Geological Survey Open-File Report 81-503, p. 48-50.

Karish, C.R., Miller, E.L., and Sutter, J.F., 1987, Mesozoic tectonic and magmatic history of the central Mojave Desert, in Dickinson. W.R. and Klute, M.A., eds., Mesozoic rocks of southern Arizona and adjacent areas: Arizona Geological Society Digest, v. 18, p. 15-32.

Kupfer, D.H., and Bassett, A.M., 1962, Geologic reconnaissance map of part of the southeastern Mojave Desert, California: U.S. Geological Survey Mineral Investigations Field Studies Map MF-205, scale 1:125,000.

Mariano, John, Helferty, M.G., and Gage, T.B., 1986, Bouguer and isostatic residual gravity maps of the Colorado River region, including the Kingman, Needles, Salton Sea, and El Centro quadrangles: U.S. Geological Survey Open-File Report 86-347, scale 1:250,000, 7 sheets.

Miller, E.L., 1981, Geology of the Victorville region, Calaifornia: Geological Society of America Bulletin, part II, v. 92, p. 554-608.

Miller, F.K., and Morton, D.M., 1980, Potassium-argon geochronolgy of the eastern Transverse Ranges and southern Mojave Desert, southern California: U.S. Geological Survey Professional Paper 1152, 30 p.

Miller, W.J., 1944, Geology of the Palm Springs-Blythe strip, Riverside County, California: California Journal of Mines and Geology, v. 40, p. 11-72.

Moyle, W.R., Jr., 1961, Data on water wells in the Dale Valley area, San Bernardino and Riverside Counties, California: California Department of Water Resources, Bulletin 91-5, fig. 2, scale 1:62,500.

Neumann, T.R., and Leszcykowski, Andrew, 1993, Identified mineral resources of the Needles $1^{\circ} \mathrm{X} 2^{\circ}$ quadrangle, California: U.S. Department of the Interior, Bureau of Mines, Mineral Land Assessment Open File Report MLA 14-93, 349 p.

Parker, R.B., 1963, Recent volcanism at Amboy Crater, San Bernardino County, California: California Division of Mines and Geology Special Report 76, 22 p.

Phelps, G.A., Bedrord, D.R., Lidke, D.J., Miller, D.M., and Schmidt, K.M., 2011, Preliminary surficial geologic map of the Newberry Springs 30' x 60' quadrangle, California: U.S. Geological Survey OpenFile Report 2011-1044, scale 1:100,000.

Reynolds, S.J., and Spencer, J.E., 1989, Pre-Tertiary rocks and structures in the upper plate of the Buckskin Detachment Fault, west-central Arizona, in Spencer, J.E., and Reynolds, S.J., eds, Geology 
and mineral resources of the Buckskin and Rawhide Mountains, west-central Arizona: Arizona Geological Survey Bulletin 198, p. 67-102.

Richard, S.M., 1992, ed., Deformation associated with the Neogene eastern California shear zone, southeastern California and southwestern Arizona: Redlands, Calif., San Bernardino County Museums Special Publication 92-1, $78 \mathrm{p}$.

Rosen, M.R., 1989, Sedimentologic, geochemical, and hydrologic evolution of an intracontinental, closed-basin playa (Bristol Dry Lake, CA) - A model for playa development and its implications for paleoclimate: Austin, University of Texas, PhD. dissertation, $266 \mathrm{p}$.

Rosen, M.R., 1991, Sedimentologic and geochemical constraints on the hydrogeologic evolution of Bristol Dry Lake Basin, California, USA: Palaeogeography, Palaeoclimatology, Palaeoecology, v. 84, p. 229-257.

Schafer, M., Anctil, R.J., Danehy, E.A., and Coonrad, W.L,, 1959b, Geology and mineral resources of Township 5 North, Ranges 9 and 10 East, San Bernardino Base and Meridian, San Bernardino County, California: Albuquerque, N.M., Santa Fe Pacific Mining, Inc., unpublished map and report, scale 1:24,000.

Schafer, M., Cunningham, A.B., Anctil, R.J., and Danehy, E.A., 1959a, Geology and mineral resources of Township 5 North, Ranges 11 and 12 East, San Bernardino Base and Meridian, San Bernardino County, California: Albuquerque, N.M., Santa Fe Pacific Mining, Inc., unpublished map and report.

Sherrod, D.R. and Nielson, J.E., eds, Tertiary stratigraphy of highly extended terranes, California, Arizona, and Nevada: U.S. Geological Survey Bulletin 2053, 250 p.

Silver, L.T., and McKinney, C.R., 1973, U-Pb isotopic age studies of a Precambrian granite, Marble Mountains, San Bernardino County, California [abs.]: Geological Society of America Special Paper 73, p. 65.

Streckeisen, A.L., 1973, Plutonic rocks classification and nomenclature recommended by the IUGS Subcommission on the Systematics of Igneous Rocks: Geotimes, v. 18, no. 10, p. 26-30.

Thompson, D.G., 1929, The Mojave Desert region, California-A geographic, geologic, and hydrologic reconnaissance: U.S. Geological Survey Water-Supply Paper 578, 759 p.

U.S. Geological Survey, 1981, Aeromagnetic map of the Needles $1^{\circ}$ by $2^{\circ}$ quadrangle, California and Arizona: U.S. Geological Survey Open-File Report 81-85, scale 1:250,000.

Ver Planck, W.E., 1958, Salt in California: California Division of mines Bulletin 175, 168 p.

Walker, J.D., 1988, Permian and Triassic rocks of the Mojave Desert and their implications for timing and mechanisms of continental truncation: Tectonics, v. 7, p. 685-709.

Wilshire, H.G., Meyer, C.E., Nakata, J.K., Calk, L.C., Shervais, J.W., Nielson, J.E., and Schwarzman, E.C., 1988, Mafic and ultramafic xenoliths from volcanic rocks of the western United States: U.S. Geological Survey Professional Paper 1443, 179 p.

Wilshire, H.G., and Nielson-Pike, J.E., 1986, Upper-mantle xenoliths in alkaline basalt, Dish Hill, California, in Ehlig, P.L., comp., Guidebook Southern California field trips-Mojave Desert xenolith suites- Malapai Hill and Dish Hill, Peninsular Ranges batholith, and Geology and hydrology of Catalina Island, Southern California: Los Angeles, Calif., Geological Society of America Cordilleran Section 82nd Annual Meeting, March 25-28, 1986, p. 9-11.

Wright, L.A., Stewart, R.M., Gay, T.E., Jr., and Hazenbush, G.C., 1953, Mines and mineral deposits of San Bernardino County, California: California Journal of Mines and Geology, v. 49, p. 49-257. 